DOI 10.14746/ssp.2021.3.7

Beata A. OrtowsKA

Akademia im. Jakuba z Paradyża w Gorzowie Wielkopolskim

ORCID ID: 0000-0002-1711-9716

\title{
Bezpieczeństwo edukacyjne dzieci cudzoziemskich jako element bezpieczeństwa kulturowego
}

Streszczenie: Celem artykułu jest zwrócenie uwagi na kwestię gwarantowania bezpieczeństwa edukacyjnego dla cudzoziemskich dzieci. Trudności po stronie uczniów, szkolnych administracji czy nauczycieli świadczą o tym, że nie można ich zignorować. Nie można też pominąć bezpieczeństwa kulturowego, będącego podstawą bezpieczeństwa edukacyjnego. Artykuł został podzielony na kilka głównych części. Pierwsza stanowi wprowadzenie do zagadnienia bezpieczeństwa kulturowego i edukacyjnego. Kolejne części zawierają próby wyszczególnienia obszarów wsparcia dla cudzoziemskich uczniów w celu podjęcia dyskusji na temat sytuacji cudzoziemskich dzieci w polskich szkołach.

Słowa kluczowe: bezpieczeństwo kulturowe, bezpieczeństwo edukacyjne, cudzoziemcy, imigranci

\section{Wstęp}

$\mathbf{Z}$ miany, jakie zaszły w zglobalizowanym świecie spowodowały dynamiczny wzrost ruchów ludności. Przemieszczają się wszyscy - zarówno dorośli, jak i dzieci. Ich los często zależny jest od wielu różnych warunków, w tym społeczno-prawno-ekonomicznych. Regulacje związane $\mathrm{z}$ edukacją dzieci cudzoziemskich stanowią podstawę do objęcia ich systemem oświatowym. Ale uregulowania prawne, to jedno, a gotowość szkoły i pozostałych uczestników systemu szkolnego do spotkania z „Innym", to odrębna kwestia. Pod uwagę należy wziąć jeszcze to, że często ci „Inni” pochodzą z innej kultury, wyznają inną religię i bardzo często nie znają języka polskiego. Te wszystkie uwarunkowania powodują, że musi nastąpić wzrost świadomości, że „szczególnego wsparcia w tym kontekście wymagają dzieci. Wyjazd z kraju pochodzenia to duża zmiana w życiu dziecka, która może powodować trudności w odnalezieniu się w nowym otoczeniu. Dodatkowe trudności w adaptacji w szkole mogą 
wynikać ze słabej motywacji do nauki, braku pewności co do czasu pobytu w danym miejscu, często uzależnionego od otrzymanej decyzji w zakresie ochrony międzynarodowej, niskie wykształcenie rodziców, czy też częsta zmiana miejsca pobytu" (Hajduk, 2018, s. 6).

Celem artykułu jest próba zwrócenia uwagi na problemy zapewnienia bezpieczeństwa edukacyjnego dzieciom cudzoziemskim. Trudności leżące zarówno po stronie uczniów, jak i szkoły i nauczycieli powodują, że nie można przejść obojętnie wobec trudności, z którymi muszą borykać się dzieci, rodzice, szkoła i nauczyciele. Podstawową hipotezę pracy stanowiło przypuszczenie, że bezpieczeństwo edukacyjne dzieci cudzoziemskich jest zagrożone. Przypuszcza się, że struktura organizacyjna szkoły nie jest odpowiednio przygotowana na pracę z dziećmi cudzoziemskimi. Główną metodą zastosowaną podczas przygotowywania materiału była analiza dostępnych raportów, przepisów prawa i materiałów dostępnych w SIO oraz na stronach MEiN oraz analiza literatury przedmiotu z zakresu bezpieczeństwa kulturowego. Nie można nie wspomnieć też o istocie tego rodzaju bezpieczeństwa, ponieważ stanowi ono podstawę dla bezpieczeństwa edukacyjnego. Cały artykuł został podzielony na kilka zasadniczych części. W pierwszej, w oparciu o literaturę przedmiotu, dokonano wprowadzenia w zagadnienie bezpieczeństwa kulturowego i edukacyjnego. W dalszej części starano się zwrócić uwagę na występujące trudności i możliwe obszary wsparcia uczniów cudzoziemskich by przejść do omówienia sytuacji dzieci cudzoziemskich w polskich szkołach.

Migracja ludności współcześnie przebiega bardzo intensywnie i dynamicznie. Kierunki migracji i ich motywy powodują, że społeczności muszą przygotować się nie tylko na spotkanie z „Innym”, ale również na życie we wspólnocie. Ważnym więc zadaniem okazuje się prowadzenie właściwej polityki integracji imigrantów. Jednym z ważniejszych dokumentów zawierających najważniejsze zalecenia dla polityki integracji imigrantów był Komunikat Komisji Europejskiej, który został wydany w czerwcu 2003 roku, a dotyczył imigracji, integracji i zatrudnienia. Co istotne, dokument ten zawiera również wskazania dotyczące kwestii dostępu do edukacji. Komunikat ten „wyraźnie podkreśla jej znaczenie jako jednego z najważniejszych instrumentów ułatwiających integrację: Należy zauważyć, że system edukacji odgrywa zasadniczą rolę nie tylko w zdobywaniu wiedzy, ale również jako miejsce zdobywania formalnych i nieformalnych informacji o normach i wartościach społeczeństwa, a także jako pomost międzykulturowy. Jest on ważnym narzędziem zachęcania do pluralizmu i różnorodności, zarówno w stosunku do popula- 
cji imigrantów, jak i społeczeństwa kraju goszczącego, sprzyjając przez to zwalczaniu dyskryminacji” (Communication, brw, s. 10).

\section{Bezpieczeństwo kulturowe i edukacyjne}

Analizując bezpieczeństwo jako dziedzinę wiedzy trzeba mieć świadomość, że obejmuje ona bardzo szeroki zakres różnorodnych problemów, których nie można jednoznacznie określić. Bezpieczeństwo ,jest wartością, której znaczenie docenia codziennie każdy człowiek i całe społeczeństwo. Jest obiektem starań, troski i dążeń, pragnień i zabiegów ludzi. Potrzeba bezpieczeństwa należy do najważniejszych, najbardziej podstawowych potrzeb psychicznych. Niezaspokojenie jej powoduje nie tylko doraźne przeżycia lękowe, może też prowadzić do trwałych zaburzeń w funkcjonowaniu układu nerwowego" (Pieczywok, 2015, s. 457).

Jak się okazuje jedną z istotnych możliwości do wykorzystania w procesie kształtowania poczucia bezpieczeństwa jest właśnie edukacja. Jak podkreśla Andrzej Pieczywok „stanowi ona jedną z podstawowych dróg kształtowania bezpieczeństwa człowieka - wpływa na jego postawy, wartości, wiadomości i umiejętności niezbędne w zapobieganiu, radzeniu sobie w sytuacjach zagrożeń i usuwaniu ich skutków. Jednym z istotnych obszarów w edukacji jest jej ciągłość. Zasadność tego stwierdzenia w sposób komplementarny wyraził w swoim raporcie J. Delors (Edukacja, 1998, s. 85-98): „Uczyć się, aby wiedzieć. Uczyć się, aby działać. Uczyć się, aby żyć wspólnie. Uczyć się, aby być” (Pieczywok, 2015, s. 457).

Edukacja jest szansą na zmianę, zmianę która powinna stanowić drogę ku lepszej przyszłości. Jednocześnie edukacja powinna dawać bezpieczeństwo. Jak zwraca uwagę Andrzej Pieczywok „edukacja to proces zdobywania wiedzy, na który składa się zarówno wychowanie, jak i kształcenie, które powiększa stan wiedzy danej osoby oraz rozwija określone cechy i umiejętności”" (Pieczywok, 2015, s. 458). Nie należy przy tym zapominać, że „,edukacja to ogół procesów, których celem jest zmienianie ludzi, stosownie do panujących w danym społeczeństwie ideałów i celów wychowawczych" (Zalewski, 2001, s. 41).

Każde państwo w ramach bezpieczeństwa kulturowego gwarantuje również bezpieczeństwo edukacyjne zarówno swoim obywatelom, jak również proponuje, w miarę możliwości i uregulowań prawnych, również bezpieczeństwo edukacyjne przedstawicielom pochodzącym z mniejszo- 
ści narodowych i etnicznych. Analizując ustawę o mniejszościach narodowych i etnicznych oraz o języku regionalnym (Dz. U. 2005, Nr 17, poz. 141), która obecnie obowiązuje w Polsce stwierdzić należy, że mamy w Polsce dziewięć grup zaliczanych do mniejszości narodowych i cztery grupy zaliczone do mniejszości etnicznych. Jest to o tyle istotne, że ustawa reguluje kwestie m.in. edukacji dzieci pochodzących z mniejszości narodowych i etnicznych. Daje to przedstawicielom poszczególnych grup mniejszościowych możliwość podtrzymywania własnej tożsamości i prowadzenia edukacji w języku narodowym. Sytuacja ta daje pewną stabilizację i bezpieczeństwo, oczywiście jeśli jest właściwie realizowana. Jednak dotyczy to dzieci pochodzących z mniejszości. A co z dziećmi cudzoziemskimi, które przybyły do Polski np. wraz z rodzicami i które również podlegają procesowi obowiązkowej edukacji w polskiej szkole? Czy ich bezpieczeństwo edukacyjne jest zachowane? Czy nie powinniśmy lepiej przyjrzeć się jak przebiega ten proces, jak radzą sobie dzieci cudzoziemskie i czy można mówić w ich przypadku o gwarancji bezpieczeństwa edukacyjnego dla nich? Te i wiele innych pytań powodują, że należy przyjrzeć się temu bliżej.

By móc mówić o edukacji i bezpieczeństwie edukacyjnym dzieci cudzoziemskich w polskiej szkole warto jest spróbować wyjść od pytań, które stawia nauczycielom m.in. Edyta Januszewska: „Czy w dobie globalizacji, konfliktów zbrojnych i migracji ekonomicznych polska szkoła jest otwarta i gotowa na spotkanie z «Innym» (a nie z «Obcym»)? Czy nauczyciele posiadają kompetencje międzykulturowe do pracy z dzieckiem cudzoziemskim szukającym bezpieczeństwa i godnych warunków do życia w polskim demokratycznym społeczeństwie? Czy nauczyciele przygotowują polskich uczniów do międzykulturowego uczenia się i przeciwstawiania się wrogości, dyskryminacji, nietolerancji i ignorancji wobec «Innych», odmiennych kulturowo? I w końcu, czy sami są gotowi na kontakt i dialog z dzieckiem pochodzącym z innej, czasami bardzo odmiennej kultury?" (Januszewska, 2017, s. 149). Pytania te pokazują jak wiele jeszcze jest do zrobienia. A przecież różne sytuacje wymagają różnych, czasami bardzo odmiennych reakcji, przepisów i zachowań.

W 2001 roku na 31 sesji Konferencji Generalnej UNESCO została przyjęta jednomyślnie Powszechna Deklaracja o Różnorodności Kulturowej, w której podkreślono m.in., że „w naszych coraz bardziej zróżnicowanych społeczeństwach staje się konieczne zapewnienie harmonijnego wzajemnego oddziaływania oraz woli współistnienia osób i grup, które 
cechuje tożsamość kulturowa zarazem mnoga, różnorodna i dynamiczna. Polityki popierające integrację oraz uczestnictwo wszystkich obywateli są gwarantem spójności społecznej, żywotności społeczeństwa obywatelskiego oraz pokoju. Zdefiniowany w ten sposób pluralizm kulturowy stanowi polityczną odpowiedź na istnienie różnorodności kulturowej. Pluralizm kultur, nierozerwalnie związany z kontekstem demokratycznym, sprzyja wymianie kulturalnej i rozwijaniu zdolności twórczych, które wzbogacają życie społeczne" (Powszechna Deklaracja, 2001, s. 2). Zawarte w Deklaracji artykuły zwracają uwagę na kilka zasadniczych kwestii dotyczących zarówno tożsamości, pluralizmu, różnorodności (artykuły 1-3), różnorodności kulturowej i praw człowieka (artykuły 4-6), różnorodności kulturowej i twórczości (artykuły 7-9), różnorodności kulturowej i solidarności międzynarodowej (artykuły 10-12). Jedną z głównych linii działania wskazaną do realizacji w tym zakresie jest m.in.: ,popierać wymianę wiedzy i najbardziej odpowiednich działań w zakresie pluralizmu kultur, w celu ułatwienia, w społeczeństwach zróżnicowanych, integracji oraz uczestnictwa osób i grup pochodzących z różnych horyzontów kulturowych" (Powszechna Deklaracja, 2001, s. 5). Ułatwienie uczestnictwa w społeczeństwach zróżnicowanych może być realizowane przy wykorzystaniu edukacji i prowadzeniu działań integrujących dzieci cudzoziemskie z ich rówieśnikami. Szkoła jako miejsce znane dziecku, dające bezpieczeństwo i kontakt z rówieśnikami stanowi dobre podłoże do budowania bezpieczeństwa edukacyjnego, które nie pozostawi dziecka bez należytej opieki, wsparcia i pomocy w adoptowaniu się do nowego miejsca.

Nie możemy zapominać o tym, że dzieci mają swoje prawa. Prawa dziecka zostały podzielone na kategorie, które pozwalają wyróżnić pewne obszary takie jak: prawa osobiste, prawa polityczne (publiczne), prawo socjalne i prawa ekonomiczne (a w tym prawo do nauki) (RPO, 2018). Prawo do nauki jest szeroko rozumianym postulatem dającym nie tylko zgodę na chodzenie do szkoły, ale też uzyskanie wszelkiej pomocy $\mathrm{w}$ razie trudności związanych $\mathrm{z}$ edukacją.

\section{Dzieci cudzoziemskie w polskiej szkole}

Co do dzieci cudzoziemskich, jak zwraca uwagę Szymon Hajduk, pierwszym przypadkiem są dzieci korzystające z ochrony międzynarodowej. Dzieci te „korzystają z nauki i opieki w publicznych przedszkolach, 
szkołach podstawowych oraz ponadpodstawowych na warunkach dotyczących obywateli polskich, do ukończenia 18 lat lub ukończenia szkoły ponadpodstawowej. Dzieci niebędące obywatelami polskimi, a podlegające obowiązkowi nauki oraz słabo znające język polski mają prawo do pomocy udzielanej przez tzw. asystenta międzykulturowego - osobę władającą językiem kraju pochodzenia, zatrudnioną w charakterze pomocy nauczyciela" (Hajduk, 2018, s. 6). Patrząc na dostępne przepisy wydaje się, że sytuacja dzieci cudzoziemskich w polskich szkołach nie jest taka najgorsza. A jednak do końca tak nie jest. Brak finansów, a co za tym idzie braki wśród nauczycieli wspomagających (tzw. asystentów międzykulturowych) powodują, że część przepisów jest nierealizowana. W związku z tym trudno jest wspierać uczniów cudzoziemskich i pomagać nauczycielom w ich adaptacji jeśli nie będzie finansowej podpory, która zresztą jest gwarantowana ustawą.

Ważnym obszarem wsparcia dla dzieci przybywających do Polski jest wszelka pomoc umożliwiająca im jak najszybsze wejście w nowe środowisko. Jak podkreśla Szymon Hajduk z Urzędu do Spraw Cudzoziemców „w ramach udzielanej pomocy socjalnej Urząd do Spraw Cudzoziemców zapewnia lekcje języka polskiego dla dzieci, które polegają na pomocy w odrabianiu lekcji i zajęciach wyrównawczych, jak również zajęciach przygotowujących nowoprzybyłych uczniów do podjęcia nauki w polskich szkołach. Nauczyciel prowadzący zajęcia pozostaje w kontakcie ze szkołami, do których uczęszczają dzieci, co pozwala na wymianę informacji o postępach i problemach w nauce dając możliwość dostosowania prowadzonych zajęć do potrzeb dzieci. Dodatkowo, Urząd zaopatruje uczniów - tych, którzy nie otrzymują ich w szkołach - w podręczniki oraz wyposaża wszystkie dzieci realizujące obowiązek szkolny lub obowiązek nauki w tzw. wyprawki szkolne" (Hajduk, 2018, s. 6).

Jak zwraca uwagę A. Janowski ,sytuacje uczniów cudzoziemskich kształcących się w polskich placówkach oświatowych możemy zdefiniować jako proces, na który składają się codzienne i niezliczone interakcje zachodzące pomiędzy poszczególnymi aktorami społecznymi kreującymi przestrzeń szkoły. Podstawowymi aktorami są uczniowie (zarówno polscy, jak i cudzoziemscy), ich rodzice oraz personel pedagogiczny szkoły (nauczyciele, dyrektor, pedagog i psycholog szkolny). Zachodzące między nimi relacje są kształtowane przez prawne i organizacyjne uwarunkowania pracy szkoły, właściwości, oczekiwania, doświadczenia i kompetencje aktorów, ich zdolność i chęć komunikowania i negocjowa- 
nia dokonującej się relacji, umiejętność krytycznej i refleksyjnej analizy szkolnej rzeczywistości, jak również zdolność projektowania i korygowania tej rzeczywistości. Szczególną rolę w owych procesach odgrywa świadomość personelu pedagogicznego szkoły, przede wszystkim ich percepcja specyficznych problemów i potrzeb uczniów, świadomość wynikających z nich wyzwań i zadań oraz gotowość ich podejmowania" (Błeszyńska, 2010, s. 10).

Kiedy pojawia się dziecko cudzoziemskie w szkole głównym zadaniem jest jak najszybsze włączenie go w proces edukacji. Pojawia się więc pytanie o bariery, na które może napotkać zarówno uczeń, jak i szkoła wraz z kadrą, które będzie trzeba pokonać by dziecko mogło w pełni skorzystać z prawa do nauki i zagwarantować mu bezpieczeństwo edukacyjne w nowych warunkach. Polska dostosowuje się do nowych i coraz bardziej zróżnicowanych warunków obecności uczniów cudzoziemskich w szkole. Tworzone są nowe procedury i nowe przepisy, które w znaczący sposób mają ułatwić dzieciom wejście w realizację obowiązku szkolnego, a szkołom pomóc w realizacji tego obowiązku i odpowiednim zorganizowaniu pracy z uczniem. Przede wszystkim „aby umożliwić szybkie i efektywne włączenie uczniów przybywających z zagranicy do polskiego systemu oświaty od 2016 r. umożliwiono szkołom publicznym, a od 1 września 2017 r. także niepublicznym, tworzenie oddziałów przygotowawczych. Do takiego oddziału może zostać zakwalifikowany uczeń, jeśli nie zna lub słabo zna język polski, ma trudności adaptacyjne związane z różnicami kulturowymi lub ze zmianą środowiska edukacyjnego spowodowane na przykład wcześniejszym kształceniem za granicą lub trudności spowodowane przez sytuacje kryzysowe lub traumatyczne, wynikające z konfliktów zbrojnych, klęsk żywiołowych lub innych kryzysów humanitarnych" (Przyjmowanie, 2018, s. 7).

Proces przyjmowania dzieci cudzoziemskich do szkół regulowany jest przez przepisy prawa. Jak zwraca uwagę Barbara Skaczkowska z MEN ,wszystkie dzieci przybywające z zagranicy, będące w wieku 7-18 lat, w tym także te, które ubiegają się lub podlegają ochronie międzynarodowej korzystają z nauki w szkołach publicznych na takich samych zasadach, jak dzieci polskie. Dzieci ubiegające się o przyjęcie do szkoły obwodowej, tj. szkoły podstawowej znajdującej się w miejscu ich zamieszkania, są przyjmowane z urzędu. Oznacza to, że szkoła obwodowa nie może odmówić przyjęcia ucznia. Natomiast w przypadku szkół podstawowych, które znajdują się poza obwodem, szkół ponad- 
podstawowych, takich jak liceum, technikum, branżowa szkoła I i II stopnia, szkół artystycznych i sportowych uczniowie są przyjmowani, jeśli szkoła posiada wolne miejsca. Ta sama zasada obowiązuje w przypadku dotychczasowych szkół ponadgimnazjalnych" (Przyjmowanie, 2018, s. 7).

Ważnym elementem jest określenie czasu, w jakim uczeń będzie pod opieką szkoły i nauczycieli. Zakłada się, że uczeń cudzoziemski spędzi rok szkolny w szkole, do której został zapisany. Jednak „biorąc pod uwagę jego postępy rada pedagogiczna może zdecydować o skróceniu lub wydłużeniu okresu nauki, w tym przypadku - nie więcej jednak niż o jeden rok szkolny. W oddziale przygotowawczym prowadzi się naukę języka polskiego jako obcego w wymiarze nie mniejszym niż 3 godz. tygodniowo, a jednocześnie uczeń realizuje podstawę programową w sposób dostosowany do jego możliwości oraz znajomości języka polskiego. Oddziały mogą liczyć nie więcej niż 15 uczniów. Ponadto wszyscy uczniowie-cudzoziemcy w polskich szkołach, którzy nie znają albo słabo znają język polski, mają prawo do dodatkowej nauki języka polskiego w wymiarze minimum 2 godzin tygodniowo i do dodatkowych zajęć wyrównawczych, jeśli tego potrzebują. Łączny tygodniowy wymiar tych dodatkowych zajęć wynosi 5 godzin w tygodniu" (Przyjmowanie, 2018, s. 7).

Tomasz Żółciak zwraca uwagę, że proponowane obecnie zmiany w polskim prawie umożliwiałyby edukację dzieci cudzoziemskich tylko w ośrodkach dla cudzoziemców. Głównym argumentem, który podaje się po pierwszy w propozycji takiego rozwiązania to odciążenie lokalnych szkół kiedy dzieci cudzoziemskich zacznie być więcej. Kolejnym argumentem, który podaje się za izolacją edukacji dzieci cudzoziemskich jest kontekst minimalizowania negatywnego postrzegania cudzoziemców przez lokalną społeczność. Zdaniem MSWiA takie podejście „w pewnym momencie umożliwi dzieciom uchodźców „płynną adaptację” w polskiej szkole. Decyzję o tym, czy będą one uczone w ośrodku, a nie w normalnej placówce (gdzie w pierwszym roku obecnie mogą liczyć na dodatkowe zajęcia, np. z języka polskiego), samorządy podejmą w porozumieniu z szefem Urzędu do Spraw Cudzoziemców” (Żółciak, 2018).

Patrząc na poniższą tabelę opracowaną na podstawie danych uzyskanych z portalu www.migracje.gov.pl w 2020 roku widać, że dzieci cudzoziemskie nie stanowią małej liczby. Z liczby ponad 48 tys. ponad 35 tys. to dzieci w wieku przedszkolnym i podlegające obowiązkowi szkolnemu. 
Tabela 1

\section{Liczba dzieci i mlodzieży cudzoziemców} w wieku 0-18 lat

\begin{tabular}{|c|c|}
\hline Wiek & Liczba osób \\
\hline $0-3$ lata & 12597 \\
\hline $4-6$ lat & 8601 \\
\hline $7-15$ lat & 20154 \\
\hline 16-18 lat & 6822 \\
\hline Suma & 48174 \\
\hline
\end{tabular}

Źródło: Opracowanie własne na podstawie portalu https://migracje.gov.pl/statystyki/zakres/ polska/typ/dokumenty/widok/tabele/rok/2020/, 14.02.2020.

Dokonując analizy statystycznej obecności dzieci cudzoziemskich w polskich szkołach warto zwrócić uwagę, że „w ostatnich latach liczba dzieci cudzoziemskich w polskich szkołach znacząco wzrosła. W zeszłym roku szkolnym (2019 przyp. autorki) było to 44 tys. dzieci uczących się w ponad 7 tys. szkół, rok wcześniej - 30 tys. dzieci w prawie 6 tys. szkół, a w roku szkolnym 2015/16 - 14 tys. dzieci w ponad 3 tys. szkół. Według danych z 2018 r. najwięcej cudzoziemców uczyło się w szkołach w województwach: mazowieckim, dolnośląskim i małopolskim" (44 tys. dzieci..., 2020).

Pokazane liczby wskazują, że z każdym rokiem zwiększa się obecność dzieci cudzoziemskich w Polsce. Oznacza to, że nie będzie łatwo szkole zorganizować edukację w coraz bardziej zróżnicowanej grupie uczniów. Dodatkowo dochodzi jeszcze kwestia monitorowania liczby uczniów w poszczególnych szkołach i wiele innych obszarów, z którymi musi zmierzyć się szkoła. Wsparcie w tym zakresie miał dać i chyba po części dał System Informacji Oświatowej, który powstał w 2005 roku. Nadal podlega on pewnym modyfikacjom by lepiej służyć monitorowaniu informacji dotyczącej m.in. liczby uczniów. SIO prowadzone jest przez Ministerstwo Edukacji Narodowej i w swoich założeniach ,system ten zakłada kolekcjonowanie danych dotyczących m.in. liczby uczniów niebędących obywatelami polskimi, z podziałem na ich status prawny, oraz liczbę słuchaczy kursów języka polskiego. Co ważne, kuratoria oświaty mają obowiązek przesyłania danych dotyczących nauki cudzoziemców w szkołach z podziałem na imigrantów pochodzących z krajów Unii Europejskiej, oraz imigrantów z krajów państw trzecich" (Szelewa, 2010, s. 25). 
Mimo różnych informacji, które możemy znaleźć w SIO system ten ma pewne mankamenty. Jednym z nich jest brak możliwości wyfiltrowania „liczby słuchaczy i uczniów w rozbiciu na poszczególne kraje pochodzenia. Stanowi to przeszkodę na drodze do odpowiedniej identyfikacji potrzeb tych grup, pochodzących z różnych, często pozaeuropejskich kręgów kulturowych i posiadających odmienne cechy określające dynamikę przystosowania się do życia w Polsce. Pomimo braku jednoznacznego wymogu ze strony Ministerstwa Edukacji, niektóre kuratoria zbierają takie informacje, co może prowadzić do zróżnicowania regionalnego w zakresie diagnozowania konkretnych potrzeb tej grupy ludności" (Szelewa, 2010, s. 25-26).

Analizując możliwości nauki dzieci cudzoziemskich w polskich szkołach widać wyraźnie, że w większości uczniowie-cudzoziemcy uczą się wspólnie z polskimi rówieśnikami. Ci, którzy nie znają języka polskiego lub ich znajomość języka polskiego jest bardzo niska, mają możliwość „dodatkowej nauki języka polskiego w wymiarze minimum 2 godzin tygodniowo i do dodatkowych zajęć wyrównawczych, jeśli tego potrzebują. Łączny tygodniowy wymiar tych dodatkowych zajęć wynosi 5 godzin w tygodniu" (www.gov.pl, 2019). Z danych prezentowanych przez SIO wynika, że obecnie w Polsce w przedszkolach, szkołach i szkołach policealnych w roku szkolnym 2018/2019 było około 44 tys. cudzoziemców. Z tej liczby status uchodźcy posiadało 206 osób, o ochronę międzynarodową ubiegało się 778 osób, inne formy ochrony międzynarodowej (np. pobyt tolerowany czy pobyt ze względów humanitarnych) posiadało 1747 osób" (www.gov.pl, 2019).

Gwałtowny napływ cudzoziemców wraz z dziećmi w wieku szkolnym do Polski po 2016 roku spowodował, że szkoła musiała rozpocząć proces umożliwiający włączenie się nowoprzybyłych z zagranicy uczniów do polskiego systemu oświaty. W związku z tym od 1 września 2017 r. rozpoczęto możliwość tworzenia oddziałów przygotowawczych. Od tego czasu „do takiego oddziału może zostać zakwalifikowany uczeń, jeśli nie zna lub słabo zna język polski, ma trudności adaptacyjne związane z różnicami kulturowymi lub ze zmianą środowiska edukacyjnego spowodowane na przykład wcześniejszym kształceniem za granicą lub trudności spowodowane przez sytuacje kryzysowe lub traumatyczne, wynikające z konfliktów zbrojnych, klęsk żywiołowych lub innych kryzysów humanitarnych" (www.gov.pl, 2019). Ważnym elementem, który pozwala na szybką reakcję i pomoc uczniom-cudzoziemcom jest możliwość tworzenia takich oddziałów również w trakcie roku szkolnego, 
np. ze względu na pojawienie się większej liczby uczniów z zagranicy. Brak konieczności czekania do rozpoczęcia kolejnego roku szkolnego by otworzyć taki oddział umożliwia szybsze rozpoczęcie procesu adaptacji dziecka cudzoziemskiego w nowym środowisku. Z informacji zawartych w SIO w roku szkolnym 2018/2019 w oddziałach przygotowawczych w zajęciach uczestniczyło około 300 uczniów. Szkoda natomiast, że SIO nie zawiera informacji na temat zatrudnianych $\mathrm{w}$ charakterze pomocy nauczycieli. Szczególnie w tych oddziałach, w których pracują oni w grupach mieszanych z dziećmi cudzoziemskimi. Informację o zatrudnieniu takich osób posiada tylko samorząd właściwy dla konkretnej szkoły jako organ prowadzący (www.gov.pl, 2019).

Jak wynika z opisanych powyżej procedur sprawa wydaje się prosta i nieskomplikowana. Jednak kiedy zagłębimy się w szczegóły okoliczności związanych z migracją dziecka, rozpatrzymy jego status prawny związany z pobytem na terenie Polski to możemy mieć do czynienia z różnymi sytuacjami. Mogą nam się wyłonić dwie różne kategorie: uchodźca i imigrant. Jak podkreśla Krystyna Błeszyńska „obie te kategorie, mimo wspólnoty doświadczenia, jakim jest migracja oraz konieczność pobierania nauki w kulturowo i językowo obcym środowisku, różnią się statusem prawnym oraz specyfiką i nasileniem potrzeb związanych z problemami o charakterze zdrowotnym i emocjonalnym. Na grupę imigrantów składają się dzieci osób przesiedlających się do Polski z zamiarem pozostania w Polsce na stałe oraz dzieci osób migrujących jedynie czasowo. Większość z nich przybywa z obszarów wschodnich sąsiadów naszego kraju (przede wszystkim z Rosji, Białorusi i Ukrainy), Ameryki Północnej i państw Europy Zachodniej, wzrasta jednak liczba osób pochodzących spoza kręgu kultur euroamerykańskich; są to imigranci przede wszystkim z Azji Południowej i Wschodniej, Bliskiego Wschodu oraz Afryki. Najliczniejszą spośród grup azjatyckich są Wietnamczycy" (Błeszyńska, 2010, s. 10-11).

Przybywających do Polski imigrantów często różni bardzo wiele - od statusu prawnego, po język, religię czy kulturę pochodzenia. Inne może być ich pochodzenie etniczne, reprezentują inny status materialny i społeczny. Ważnym elementem jest też zdolność do przystosowania się do nowych warunków, a w tym chęć do edukacji czy przyuczenia do nowego zawodu. Jak podkreśla K. Błeszyńska „problemy, których doświadczają rodzice i opiekunowie, oraz przejawiane przez nich postawy wobec Polski i pobytu na jej terytorium przekładają się na sytuacje dzieci, wpływając na ich motywacje i możliwości nauki” (Błeszyńska, 2010, s. 11). 
Te zasygnalizowane, tylko najważniejsze, motywy można jeszcze poszerzyć m.in. o problemy językowe. Pamiętać należy, że ,większość dzieci obcokrajowców nie zna języka polskiego lub włada nim w stopniu niewystarczającym wobec wymagań polskiej szkoły. Wszystkie doświadczają problemów towarzyszących zmianie warunków życia, środowiska społecznego oraz środowiska kulturowego. Wzmiankowane trudności nasilają się jednocześnie u uczniów starszych, ponieważ towarzyszą im napięcia związane z okresem dorastania i formowania struktur tożsamościowych" (Błeszyńska, 2010, s. 11-12).

Oczywiście z podobnymi problemami muszą zmagać się dzieci uchodźców. Zgodnie z Konwencją genewską z 1951 roku (Dz. U. 1991, Nr 119, poz. 515) uchodźcą jest osoba, która opuszcza „kraj swego pochodzenia z powodu uzasadnionej obawy przed prześladowaniem ze względu na rasę, religię, narodowość, poglądy polityczne lub przynależność do określonej grupy społecznej (Dz. U. 2003, Nr 128, poz. 1175). W rozumieniu potocznym są to osoby migrujące ze względu na zagrożenia związane z sytuacjami opresji politycznej, prześladowań religijnych, konfliktów zbrojnych, a także klęsk żywiołowych. W Polsce o status uchodźcy stara się 3-4 tys. osób w skali roku. Istniejące przepisy prawne umożliwiają efektywne monitorowanie sytuacji tej grupy. Uczniowie zaliczający się do owej kategorii na ogół przybywają do Polski w towarzystwie swoich prawnych opiekunów. Zdarzają się jednak sytuacje, kiedy z powodu braku takowej opieki pozycje prawnego reprezentanta i opiekuna interesów dziecka przejmują władze kraju osiedlenia się" (Błeszyńska, 2010, s. 12).

Patrząc na sytuację dzieci uchodźców z perspektywy bezpieczeństwa edukacyjnego trzeba mieć świadomość specyficznej sytuacji, w jakiej znalazły się te dzieci przybywając do Polski. W związku z tym wymaga to od placówek oświatowych i wychowawczych odpowiedniego przygotowania. Trzeba pamiętać, że dzieci te przybywają do naszego kraju często po przeżytych różnych dramatach. Te „dramatyczne na ogół okoliczności towarzyszące migracji tej kategorii osób oraz przeżycia w drodze do kraju przyjmującego powodują liczne zaburzenia fizyczne i psychiczne funkcjonowania dziecka, niekorzystnie rzutując na procesy jego rozwoju i socjalizacji. Bardzo często tego rodzaju doświadczenia ograniczają zdolności uczenia się i nawiązywania kontaktów społecznych. Procedury uchodźcze oraz związane z nimi długotrwałe przebywanie w ośrodkach recepcyjnych lub opiekuńczych generują natomiast poczucie niepewności, ograniczając motywacje do nauki. Specyficzne problemy dzieci 
uchodźczych znajdują wyraz w niepowodzeniach odnoszonych w nauce szkolnej. Jak wskazują dane UNHCR, ponad połowa dzieci uchodźców w Polsce nie realizuje obowiązku szkolnego, a wśród tych, które uczęszczają do szkoły, połowa nie przystępuje do egzaminów z języka polskiego, pozostałe zaś napotykają na liczne problemy wynikające z nakładania się odmienności kulturowej, traumatycznych doświadczeń migracyjnych, nieznajomości języka polskiego oraz nieadekwatnej pracy placówek oświatowych" (Błeszyńska, 2010, s. 12-13). Już tylko te wskazane problemy pokazują z czym muszą zmagać się dzieci cudzoziemskie i wyraźnie rysuje się obraz problemów, z jakimi muszą poradzić sobie również szkoły i nauczyciele. Stąd konieczność zwrócenia uwagi i próby wypracowania działań, które pozwolą wspierać uczniów w różnych obszarach. Warto przy tym podkreślić rolę asystentów międzykulturowych zarówno w szkołach, jak i np. placówkach typu poradnie psychologiczno-pedagogiczne, gdzie wsparcie to staje się coraz bardziej potrzebne.

\section{Zakończenie}

Pamiętać należy, że zasygnalizowane powyżej trudności i problemy to tylko te najbardziej charakterystyczne, które mogą generować kolejne. Każdy przypadek dziecka cudzoziemskiego jest odrębną historią, z którą należy się wnikliwie zapoznać by pomoc dziecku była tą jakiej potrzebuje. Podkreślić też warto, że brak znajomości języka polskiego nie będzie ułatwiał opanowania wiedzy. Może natomiast generować u dziecka liczne trudności w nauce. W konsekwencji może to prowadzić do niepowodzeń szkolnych, które mogą skutkować powtarzaniem klasy. To natomiast nie będzie elementem mobilizującym do dalszej nauki. W konsekwencji zaobserwujemy efekt domina, który spowoduje, że dzieci obciążone wieloma trudnościami nie tylko przestaną w ogóle się uczyć ale dodatkowo może to doprowadzić do różnego rodzaju zaburzeń. Te zasygnalizowane trudności pokazują, że szkoła powinna być dobrze przygotowana na przyjęcie dzieci cudzoziemskich. Nauczyciele pracujący z grupą wielokulturową powinni być wyposażeni w kompetencje międzykulturowe ułatwiające prace z dziećmi z różnych kręgów kulturowych. Podobne kompetencje powinna nabyć też obsługa szkoły by móc nieść pomoc dzieciom w różnych sytuacjach. Omówione powyżej zagadnienia i trudności pokazują, że polska szkoła wymaga dopracowania w kwestii bezpieczeństwa edukacyjnego dzieci cudzoziemskich. 
Pamiętać też należy, że bez ścisłej współpracy nauczycieli i rodziców czy prawnych opiekunów dziecka nie będzie możliwe zapewnienie mu właściwej edukacji. A tylko zapewnienie bezpieczeństwa edukacyjnego i wsparcie na linii szkoła-nauczyciel-rodzic/opiekun będzie możliwe szybkie i w miarę bezpieczne włączenie się dziecka cudzoziemskiego w nowe środowisko, oczywiście starając się jednocześnie zachować ich własną tożsamość. Warto tu też podkreślić, że Polska ma regulacje prawne dające szansę na zaoferowanie pomocy i wsparcia dzieciom cudzoziemskim w obszarze edukacji jednak, jak pokazuje praktyka szkolna, działania te wymagają jeszcze dopracowania.

\section{Bibliografia}

Błeszyńska M. K. (2010), Dzieci obcokrajowców w polskich placówkach oświatowych perspektywa szkoty. Raport z badań, ORE, Warszawa.

Communication from the Commission to the Council, the European Parliament, the European Economic and Social Committee and the Committee of the Regions on immigration, integration and employment, COM/2003/0336 final.

Dz. U. 1991, Nr 119, poz. 515 - Konwencja dotycząca statusu uchodźców sporządzona w Genewie dnia 28 lipca 1951 roku.

Dz. U. 2003, Nr 128, poz. 1175 - ustawa z dnia 13 czerwca 2003 r. o cudzoziemcach.

Dz. U. 2005, Nr 17, poz. 141 - ustawa o mniejszościach narodowych i etnicznych oraz o języku regionalnym z 6 stycznia 2005 r. z późn. zmianami.

Edukacja - jest w niej ukryty skarb (1998), Raport dla UNESCO, Międzynarodowej Komisji do spraw Edukacji dla XXI wieku pod przewodnictwem Jacques'a Delorsa, Warszawa.

Hajduk S. (2018), Edukacja dzieci w trakcie procedury uchodźczej, Urząd do Spraw Cudzoziemców, Biuletyn informacyjny kwiecień.

https://migracje.gov.pl/statystyki/zakres/polska/typ/dokumenty/widok/tabele/ $\mathrm{rok} / 2020 /, 14.02 .2020$.

Januszewska E. (2017), Uczniowie cudzoziemscy w polskiej szkole - między integracja a marginalizacja, ,Studia Edukacyjne”, $\mathrm{nr} 43$, https://repozytorium.amu. edu.pl/bitstream/10593/22355/1/SE_43_2017_Edyta_Januszewska.pdf.

Pieczywok A. (2015), Bezpieczeństwo jako wartość edukacyjna i badawcza, w: „Rodzinna Europa" europejska myśl polityczno-prawna u progu XXI wieku, red. P. Fikus, H. Malewski, M. Marszal, E-Wydawnictwo, Prawnicza i Ekonomiczna Biblioteka Cyfrowa, Wydział Prawa, Administracji i Ekonomii Uniwersytetu Wrocławskiego, Wrocław.

Powszechna Deklaracja o Różnorodności Kulturowej-UNESCO 2001, https://www. unesco.pl/fileadmin/user_upload/pdf/Powszechna_Dekl_o_roznorodnosci. pdf. 
Przyjmowanie dzieci cudzoziemców do polskich szkót, przyznawanie subwencji oświatowych oraz wsparcie edukacyjne (2018), Urząd do Spraw Cudzoziemców, Biuletyn informacyjny kwiecień.

RPO, publ., www.brpd.gov.pl/prawa_dziecka, 27.12.2018.

Szelewa D. (2010), Integracja a polityka edukacyjna, Centrum Stosunków Międzynarodowych, Raporty i Analizy. Seria „Integracja”, http://csm.org.pl/fileadmin/ files/Biblioteka_CSM/Raporty_i_analizy/2010/CSM\%20Raporty\%20i\%20 Analizy\%20Integracja\%20a\%20Polityka\%20Edukacyjna\%20P.pdf.

Zalewski S. (2001), Polityka bezpieczeństwa państwa a edukacja obronna, Warszawa.

Żółciak T. (2018), Dzieci gorszego Boga. Polska stworzy getta edukacyjne dla uchodźców, GazetaPrawna.pl z 26.02.2018 r., https://serwisy.gazetaprawna.pl/edukacja/artykuly/1106995,getta-edukacyjne-dla-uchodzcow.html, 14.02.2020.

44 tys. dzieci cudzoziemskich w polskich szkołach, Gość.pl, nr 22/2020, https://info. wiara.pl/doc/5869052.44-tys-dzieci-cudzoziemskich-w-polskich-szkolach.

https:/www.gov.pl/web/edukacja/nauka-dzieci-przybywajacych-z-zagranicy-wpolskim-systemie-edukacji.

\section{Educational Security of Foreign Children as an Element of Cultural Security}

\section{Summary}

The purpose of the article is to try to draw attention to the problems of ensuring educational safety for foreign children. Difficulties lying on the side of students as well as school and teachers mean that you cannot ignore the difficulties that they face. One cannot fail to mention cultural security, which is the basis for educational security. The whole article has been divided into several main parts. The first introduces the issue of cultural and educational security. In the following part, attempts were made to highlight the areas of support for foreign students in order to discuss the situation of foreign children in Polish schools.

Key words: cultural security, educational security, foreigners, immigrants 
